\title{
A Reflective Process to Effect Meaningful Change in Pedagogical Practice
}

\author{
Maria C. Guilott, Gaylynn A. Parker, Leslie C. Owens \\ United States of America, Canada
}

\begin{abstract}
Why is an inordinate amount of money spent on professional development not yielding expected results? Much of the growth opportunities offered to teachers is a passive process that does not engage them at a level where they will commit to making a change. Educators are learners as well and need to enter the learning process in the same way students do. Even with all social and political circles clamoring for change, the decision to do things differently must come from the teacher. Sometimes a simple process can be a game changer and can motivate teachers to embark and invest in the change agenda.
\end{abstract}

\section{Introduction}

Engaging students in the learning task concerns most educators. In fact, teachers will seek ways to involve the learner, but find it difficult to empathize with their learners and forget what makes them become engaged as learners in the learning process. Teachers tend to see what they do for students as a presentation with an audience, where the students are the audience, the passive recipients of the learning. What if instead, teachers engaged in a process that fosters empathy and were willing to explore what makes the learning process engaging to them as learners and considered the importance of the tasks they put before students?

In Creating Great Schools, Philip Schlechty says, "Tasks that are themselves without meaning or value to the student require rewards extrinsic to the task to induce compliance, whereas tasks that have meaning to the student earn both the attention and commitment of the student[12].

So, the central question, then, becomes one of design. How does a teacher move from empathy to action?

If teachers used backward design in their approach and attended to the Stages of Learning, as noted in The Understanding by Design Guide to Creating High Quality Units, students would be able to transfer what they have learned to new and different context, completely on their own, "arguably the long term goal of all education." [17]. The idea for the three stages of learning was first identified in How People Learn, emphasizing that all stages are essential [10]. Wiggins and McTighe argue that although students do not engage in the three phases in any particular order, during the acquisition stage students mostly focus on a body of knowledge, emphasizing knowledge and skills where memorization is the preferred mode of learning and direct teaching is the chosen methodology. However, without this stage, there is no fluency in the learning nor is their automaticity of recall when needed in the performance of a particular task, whether new or similar to the one just used in the learning. For example, when the student has acquired the learning, he or she is able to read fluently out loud, follow concrete steps and procedures, answer questions from a text, or recall facts about a historical period. On the other hand, once the student is able to find patterns, identify rules, abstract principles, and make connections of the content learned, he or she is making his own meaning. This stage of learning must occur in the learner's head. At this stage, the learner is grappling with ideas, hypothesizing, and considering strategies. When the aim of the learning design is meaning making, the role of the instructor is no longer to direct; but to provoke inquiry and facilitate the learning process. Nevertheless, if the student is unable to take the learning to the next stage where he applies what he or she has learned, with the teacher providing decreasing cues, he or she has not really learned and has just committed material to memory, promptly to be forgotten. Conversely, if the student is able to adapt what he has learned to specific and realistic situations and contexts and has a repertoire to use, he has truly learned the material. Every teacher wants to hear what returning students at the Science Leadership Academy say, according to Larissa Pahomov, author of Authentic Learning in the Digital Age, "You taught me how to think [18] The dramatic implications for learning that ensue from a deep understanding of the Stages of Learning are worthy of note. If when offering professional development, teachers could personally experience the effect of the Stages of Learning themselves, they would likely be better disposed to change and willing to design differently. As they wonder how to design, teachers must begin to see more clearly how the role of the student and the role of teacher have to change to address the three stages of learning. Just 
following the exact same format of delivery, where the teacher tells and students memorize will only perpetuate the problem students have now when they have to downshift from their world of high tech and adapt to the current model of instruction.

\section{Research Model and Pilot Results}

A simple process that helps teachers empathize and understand themselves the impact of the Stages of Learning will be described. What if instructors looked at common, everyday practices that all teachers already use or have endured in classrooms themselves over the years? Common practices were first identified in A Value Added Decision [3] when working with a school of medicine as the teaching physicians redesigned their instructional program. Typically, even after experiencing extensive professional development, teachers in general will revert to that which is familiar and comfortable and has delivered results of some sort over the years. The list of identified strategies can vary with the grade levels but most are standard practices across K-12 schools and universities.

Following is a list of "tried and tested" pedagogical ideas selected for purposes of this discussion. At the center of this discussion are the Stages of Learning and the idea of engagement. Teacher participants are asked to identify for themselves what they, as learners, need to make a particular pedagogical practice yield the best results for them individually. The research tool is flexible and will yield tremendous insights for teachers and administrators alike. Listed below are the tried and true pedagogical practices which became our research tool.

Table 1. Boomerang Strategies Research Tool.

\begin{tabular}{|l|l|}
\hline Learner Situation & $\begin{array}{l}\text { What conditions must } \\
\text { be present for you as } \\
\text { the learner? }\end{array}$ \\
\hline $\begin{array}{l}\text { 1. When is reading text } \\
\text { engagement in meaning } \\
\text { making, leading to } \\
\text { transfer? }\end{array}$ & When... \\
\hline $\begin{array}{l}\text { 2. When is completing a } \\
\text { worksheet engagement in } \\
\text { meaning making, leading } \\
\text { to transfer? }\end{array}$ & \\
\hline $\begin{array}{l}3 . \text { When is solving a } \\
\text { problem engagement in } \\
\text { meaning making, leading } \\
\text { to transfer? }\end{array}$ & \\
\hline $\begin{array}{l}4 . \text { When is talking to a } \\
\text { peer engagement in } \\
\text { meaning making, leading } \\
\text { to transfer? }\end{array}$ & \\
\hline $\begin{array}{l}5 . \text { When is classroom } \\
\text { discussion engagement in }\end{array}$ & When.... \\
\hline
\end{tabular}

\begin{tabular}{|c|c|}
\hline $\begin{array}{l}\text { meaning making, leading } \\
\text { to transfer? }\end{array}$ & \\
\hline $\begin{array}{l}\text { 6. When is listening to a } \\
\text { lecture engagement in } \\
\text { meaning making, leading } \\
\text { to transfer? }\end{array}$ & When... \\
\hline $\begin{array}{l}\text { 7. When is taking notes } \\
\text { engagement in meaning } \\
\text { making, leading to } \\
\text { transfer? }\end{array}$ & When... \\
\hline $\begin{array}{l}\text { 8. When is writing a } \\
\text { paper engagement in } \\
\text { meaning making, leading } \\
\text { to transfer? }\end{array}$ & When... \\
\hline $\begin{array}{l}\text { 9. When is working on } \\
\text { the computer or some } \\
\text { other form of technology } \\
\text { engagement in meaning } \\
\text { making, leading to } \\
\text { transfer? }\end{array}$ & When... \\
\hline $\begin{array}{l}\text { 10. When is working on a } \\
\text { project engagement in } \\
\text { meaning making, leading } \\
\text { to transfer? }\end{array}$ & When... \\
\hline $\begin{array}{l}11 . \text { When is doing } \\
\text { homework engagement in } \\
\text { meaning making, leading } \\
\text { to transfer? }\end{array}$ & When... \\
\hline $\begin{array}{l}\text { 12. When is making a } \\
\text { presentation engagement } \\
\text { in meaning making, } \\
\text { leading to transfer? }\end{array}$ & When... \\
\hline
\end{tabular}

In October 2016, one group of instructors in Raleigh, North Carolina, participating in the activity expressed their thoughts and captured them as a group. Following are their ideas in two categories for what makes learning engaging in a manner that takes the learner to meaning making that leads to transfer. Each participant was asked to complete the form individually first. Then, the group shared their findings publicly so that what may have been implicit is now explicit. Since everyone is asked to share, no one in the group is given a pass. In this way, all participants, with no exceptions, are invested in the process. The results of this activity are not what a researcher discovered from a participant group. The results relate directly to the members of the group gathered. The facilitator of this process must seek clarification so that there are no misunderstandings. The participating group owns all ideas captured and can build on this collective wisdom to create better designs for pedagogical practice. In A Value Added Decision, the researchers noted one teacher's response in Alberta, Canada that captured the essence of teacher responses once they have experienced the process themselves, 
"It was good to hear different strategies that people use in the classroom and also to hear how each of us learns and thinks differently, recognizing that our students would be even more diverse than our small group. It was also nice to know that we could discuss teaching strategies and not be evaluated on recognizing our own flaws, but instead see them and think of how we could fix them to take students to deeper depths of learning." [3].

\section{Research Findings}

Following is an example of responses of teachers from North Carolina.

\section{Tried and Tested Teaching}

1 . When is reading text engagement in meaning making leading to transfer?

What conditions must be present for you as the learner?

- When the text is well written

- When it's interesting

- When it satisfies curiosity

- When it's accessible

- When I can annotate it

- When I am Not pressed for time

- When I can take Active- notes, underline and highlight

- When I know why the reading is important

- When it is relatable to my own experience

- When we can have a discussion afterwards

- When I see connections \& patterns with previous readings

\section{When is listening to a lecture/direct teaching} engagement in meaning making, leading to transfer?

- When it is entertaining/ engaging

-When the expertise of the speaker can be trusted

- When the lecturer is excited about what she/he is sharing

- When it is applicable to my own needs

- Helps me organize my thoughts

- When the subject \& speaker merge into one

-When I feel lecture is "taking me there" - getting me to the learning

- When the speaker uses good story-telling techniques

- When the person is knowledgeable and conveys information with compelling stories

- When there is structure/organization

- When the speaker incorporates humor

- When I have an opportunity to take notes

-When there are frequent comprehension checks

- When the speaker provides the big picture

- When there is variety in speaker's voice (not monotone)

-When the speaker is animated

- When there is interactive learning throughout
A quick read of their responses that avoid duplications makes the case why teachers like the process and do not feel in the least bit threatened, judged, or evaluated. As the teacher from Alberta, Canada explained, the process allows for teachers to share and reach a certain level of confidence that what they contribute is actually adding value to the general body of knowledge, to what they already know personally, and to what their peers know as well.

Most of these tried and tested practices have been maligned and contrasted to more innovative methods. In fact, a careful review of the list would just point to what critics say teachers are doing that is not working. However, if an instructor using the lecture method, for example, were to incorporate most of the ideas identified by the participants above, the level of engagement for the learner would increase and meaning making, leading to transfer would occur. Interestingly enough, when teachers fail to embrace the implementation of a new strategy touted by the researchers as one that will yield a high effect size, they have their own opposite research that supports their decision for no implementation. For example, EducationNext, published a research study from Harvard, Sage on the Stage that expresses the polemic on what makes an effective teacher [11]. In recent years, a consensus has emerged among researchers that teacher quality matters enormously for student performance. Students taught by moreeffective teachers learn substantially more over the course of the year than students taught by lesseffective teachers. Yet little is known about what makes for a more-effective teacher [11].

The research from Sage on Stage concluded that the lecture portion of direct instruction is one strategy that has been severely attacked as detrimental to achievement. On the other hand, when John Hattie identifies the effect size of certain influences on achievement, direct instruction has a .82 correlation where 1.0 is defined as increasing one standard deviation, a huge impact on achievement. Clearly however, after reviewing what teachers need in a lecture as expressed in below, the similarity to a Russian doll, where one doll is nested in another and so forth, is clear for direct instruction/lecture. If the instructor incorporates what teachers said they need to make the experience one that leads to meaning making and transfer, then direct instruction/lecture ceases to be a droning of words from a big talking head that ignores the students. Direct instruction comes in as the third highest on the part of the teacher as far as effect size is concerned, according to John Hattie's research that used 1200 metaanalyses to arrive at his conclusions. A Visible Learning website has demystified the process and summarized the research results and the process as follows. 
John Hattie's meta study Visible Learning [5] is a milestone of educational research. The Times Educational Supplement called it 'holy grail of teaching'. Hattie's book gives an evidence-based answer to the question 'What works best for students' achievement?'

Hattie's book is designed as a meta-meta-study that collects, compares and analyses the findings of many previous studies in education. Hattie focuses on schools in the English-speaking world but most aspects of the underlying story should be transferable to other countries and school systems as well.

Visible Learning is nothing less than a synthesis of more than 50.000 studies covering more than 80 million pupils. Hattie uses the statistical measure effect size to compare the impact of many influences on students' achievement, e.g. class size, holidays, feedback, and learning strategies [6].

Without delving into philosophical underpinnings and arguments on the improvement of pedagogical practice, participants, who became learners once again during the process discussed above, were able to identify what made each particular strategy useful to them. There was no expert in the room telling them what to do. The entire room was full of experts because everyone knows what they need to learn. The playing field was level and all participants realized that not everyone learns in the same way or needs the same conditions for learning.

A follow-up conversation concerning what they shared would capture what they can commit to doing differently based on the experience. Following is Table 2, a graphic organizer to help capture their thoughts and ideas.

Table 2. Graphic Organizer

\begin{tabular}{|l|l|l|}
\hline $\begin{array}{l}\text { Tried and } \\
\text { Tested } \\
\text { Teaching }\end{array}$ & $\begin{array}{l}\text { What } \\
\text { conditions be } \\
\text { must } \\
\text { present for you } \\
\text { as the learner? }\end{array}$ & $\begin{array}{l}\text { Teaching and } \\
\text { Learning } \\
\text { Actions }\end{array}$ \\
\hline $\begin{array}{l}\text { 1. When is } \\
\text { reading text } \\
\text { engagement } \\
\text { in meaning } \\
\text { making } \\
\text { leading to } \\
\text { transfer? }\end{array}$ & & \\
\hline
\end{tabular}

Teachers can readily see what they and their peers need. If they need these conditions, then obviously the student they teach must need them as well. They already know what they expressed individually. But, seeing the list as a group and discussing it will enrich the experience of teachers as they consider changing their pedagogical practice. Instructors could now refer to their co-created lists as they initiate planning using one of the aforementioned strategies. A quick way to ask teachers what their new teaching and learning actions will be is by having them jot down on sticky notes their ideas. Once their ideas are on paper, a conversation must follow to cement proposed changes. Essential to helping teachers make the shift is extensive dialogue where teachers are asking and answering questions. If they do not invest in the process, then it will be just another failed instructional improvement attempt on the part of the administration. Teachers will need to accept and embrace the changes they need to help students learn and engage completely in the learning process. Even if the change the teacher chooses appears to be a small one, everyone needs to celebrate with that teacher and support the initial implementation. Anyone who has tried dieting knows that change is extremely difficult and hard to stick to in the face of opposition or personal comfort. So, little changes adopted and adapted will work, not those imposed from above.

If this process has worked for commonly held teaching methods, what would happen if it were applied to more innovative practices? Teachers could begin to explore what each practice means to them and identify common misconceptions and/or misunderstandings before they include a particular "hack" into their instructional design. The idea of a hack is taken from the technology world where a user gains unauthorized access to data in a system. In this case, a hack is fully authorized but is a small step into getting full access of successful learning.

\section{Implications}

This research team recommends that teachers begin with what they already know, what is familiar, common, and habitual. After engaging in an indepth conversation with the familiar and recognizing what their actions will need to be as they design learning for students, instructors develop a level of confidence that they too are knowledgeable about learning, that they do not need an outside expert to indoctrinate them in what is needed to make learning come alive for all students, including themselves. In most cases, teachers can simply create a checklist to make sure that they have addressed the criteria they co-created for a particular tried and tested learning situation and that they have incorporated the three stages of learning so that their students can transfer their learning in the long run and on their own as Wiggins and McTighe would expect [16]. When teachers are ready to drill down deeper and make the shift from current practice to desired strategies, this process makes the transition easier. The educational experts have written extensively and provided literature to support the shift. However, the change does not happen until it is personal in some way. What better way to ease teachers into a complete 
paradigm shift than to have them come from personal experience?

By making the situation explicit, teachers are better able to support each other in the implementation of tried and tested or new strategies. To move beyond what is common practice, all instructors need to know how the changes will affect their students and them personally. The most important question that educators face is how do they get their students to transfer? What do they need to change? What do they need to offer? How do they make learning real for everyone?

Current research maintains that colleges and universities as well as $\mathrm{K}-12$ institutions are not taking students to transfer. In fact, in an article in eCampus News, Re-inventing Higher Ed, titled 4 Reasons Why a Generational Skills Gap Exists Today - and Isn't Closing, Geoff Irvine says, "Today's students believe that they are better prepared than ever to enter the workforce. However, their hiring counterparts think that the millennial generation is the most ill prepared to date - still. Incidentally, this same study revealed that employers give hiring preference to candidates who have realworld experiences; unfortunately much of what is offered today in academia isn't terribly "real world." This claim is supported by a 2015 study by Hart Research Associates conducted on behalf of the Association of American Colleges and Universities. The result of interviewing 400 employers allowed the study to note make the following observations:

*Employers value the ability to apply learning in real-world settings and broadly endorse an emphasis on applied learning experiences in college today.

$* 88 \%$ think that it is important for colleges and universities to ensure that all students are prepared with the skills and knowledge needed to complete an applied learning project.

$* 73 \%$ think that requiring college students to complete a significant applied learning project before graduation would improve the quality of their preparation for careers.

$* 60 \%$ think that all students should be expected to complete a significant applied learning project before graduating.

*Large majorities say they are more likely to consider a job candidate who has participated in an internship, a senior project, a collaborative research project, a field-based project in a diverse community setting with people from different backgrounds, or a community-based project [7].

When the World Economic Forum published The Future of Jobs and Skills in 2016, the top four skills in rank order were the following:

1. Complex Problem-solving

2. Critical Thinking

3. Creativity

4. People

5. Management
The correlation between what employers say they need in new hires and what the World Economic Forum published as the top skills necessary is obvious. To be able to accommodate the demands of the workplace in the 21 st Century, instructors at all levels must identify what is yielding positive results and what is not. If students are nodding off, appear completely disengaged in the learning, commit only to a grade or refuse to play school any more, the mandate is set.

Despite best efforts, achievement remains the same. Ironically, the process skills required by the employer community are not addressed directly in the array of wholesale solutions. If, in fact, for example, complex problem solving were given the attention it needs, then the tasks that learners are asked to do would look completely different. Students would need to be confronted with messy, complex tasks on a regular basis and would need to discern strategies and processes to solve the problem. Feedback would then become critical, not simply accidental. Self-assessment would not be a byproduct; it would be an essential component [14]. Tim Urban, in his Wait But Why blog, describes the exponential rate of change in artificial intelligence. "The chunk of time between 1995 and 2007 saw the explosion of the internet, the introduction of Microsoft, Google, and Facebook into the public consciousness, the birth of social networking, and the introduction of cell phones and then smart phones." Urban describes how a journey for a person from 1750 "when the world was in a permanent power outage, long-distance communication meant either yelling loudly or firing a cannon in the air, and all transportation ran on hay," would be shocking. The time traveler would be confronted with all our modern technology including cell phones with all their capabilities, computers, automobiles, airplanes, etc. However, that same time traveler might not be as shocked by our classrooms. When Urban describes the three kinds of artificial intelligence, he asserts that currently humans live in a world of Artificial Narrow Intelligence and that cell phones, cars, etc. are examples of a "machine intelligence that equals or exceeds human intelligence or efficiency at a specific thing." [13]. Predictions are that the rate of change in the next ten years will witness unbelievable technological changes that will alter human life as it is now. However, as stated earlier, the classrooms are still much like they were 220 years ago. Academia remains resistant to change, even in the face of accelerated changes all around.

Change is no longer an option. Academic leaders have a mandate to meet the challenges of change, which is inevitable. Managing change is the only recourse for the education world. If and when teachers accept the challenge and recognize that their teaching strategies constitute the foundation for 
Table 3. Table 3: Six Ideas Hack

\begin{tabular}{|c|c|c|}
\hline Learner situation & $\begin{array}{l}\text { What conditions must } \\
\text { be present for you as } \\
\text { the learner? }\end{array}$ & $\begin{array}{l}\text { Teaching and Learning } \\
\text { Actions }\end{array}$ \\
\hline $\begin{array}{l}\text { 1. When is learning collaboration skills } \\
\text { engagement in meaning making, leading to } \\
\text { transfer? }\end{array}$ & When... & \\
\hline $\begin{array}{l}\text { 2. When does getting feedback engage me } \\
\text { in meaning making, leading to transfer? }\end{array}$ & When... & \\
\hline $\begin{array}{l}\text { 3. When is shifting the ownership of } \\
\text { assessment to me engagement in meaning } \\
\text { making, leading to transfer? }\end{array}$ & When... & \\
\hline $\begin{array}{l}\text { 4. When is authentic/real world learning } \\
\text { engagement in meaning making, leading to } \\
\text { transfer? }\end{array}$ & When... & \\
\hline $\begin{array}{l}\text { 5. When is assessing what matters most } \\
\text { engagement in meaning making, leading to } \\
\text { transfer? }\end{array}$ & When... & \\
\hline $\begin{array}{l}\text { 6. When is using thought-provoking } \\
\text { questions engagement in meaning making } \\
\text { leading to transfer? }\end{array}$ & When... & \\
\hline
\end{tabular}

meaningful learning, conversation, collaboration, and explicit support must follow. Peer support that is not "inflicted" from above is what teachers need and appreciate. Just like all learners of the 21 st Century, teachers gravitate to sound bytes that do not tell the whole story and leave substantial pieces of the conversation unsaid. What is needed is a way for teachers to work together in a supportive capacity to effect the changes they must make in their instructional design, regardless of the discipline,

Following are six ideas from the current literature that may be explored using this process. These ideas could be considered "hacks" because they begin as small changes that yield big results when implemented in a deliberate and sound manner. Table 3 contains these six ideas in an easily identifiable format.

When the change is fairly new to the teacher's pedagogical practice, learning leaders will need to guide the process and point teachers to read or view particularly in secondary and post-secondary learning. A process, such as the one detailed earlier in this discussion that causes teachers to examine what they will need to make meaning that leads to transfer when confronted with a particular learning situation is essential. Such a design can be the event that jumpstarts teacher engagement toward committed change in pedagogical practice that will attempt to address the deficits noted in the study referenced in e-Campus News [2].

something that can yield sound bytes they can retain. The six processes listed above are drawn from the current literature and command volumes of studies and ideas. However, if school leaders are trying to implement any of them, much pre-work is needed to break down the complexity of the idea or process into useable parts that teachers can begin using immediately.

Across grade levels and for some time, educators have been discussing that learning is a social 
function that requires interaction. The Cooperative Learning process was developed to improve student engagement. However, to ensure the successful implementation of the cooperative learning process, the instructor carries most of the responsibility and slowly releases it to students. According to Luz Maria Zañartu Correa, collaborative learning is basically centered on the use of dialogue, of negotiation, of language, and learning by explanation. She further states that in a collaborative environment, there is less structure, and students are working towards independence [18].

Presently, the trend is toward collaboration, yet there is an assumption that teachers will automatically know how to incorporate it into their instructional design. If instructors are looking for ways to engage learners in collaborative experiences, an excellent reference that can be readily implemented is R. Cooper and E. Murphy's Hacking Project Based Learning. A section in the book provides a full implementation blueprint, beginning with defining and modeling what collaboration looks like, sounds like, and feels like in order to offer teachers a clear path to collaborative success, whether among students or adults. The process is the same and transfers nicely into the world of work [1]. If the pushback is that, given the amount of content to cover, there is no time left to teach such skills that students "should" already know, and then teachers will need "permission" to stop to teach the skills needed for collaboration. Sadly, at any point along the educational continuum, finger pointing and faultfinding seem to run rampant [18].

The second idea is to forward the need for feedback which John Hattie has identified, as of 2015, as carrying a .7 effect size on student achievement. In other words, less teaching and more feedback yields a higher achievement [6]. This idea seems counterintuitive because many teachers still hold on to the notion that covering more content will yield positive results in learner achievement. The opposite is actually true. Teachers must build in time to process results and apply the learning. In "Applying the Science of Learning to the University and Beyond," Halpern and Hakel note that "The single most important factor in promoting transfer is 'practice at retrieval.' This principle means that learners need to generate responses, with minimal cues repeatedly over time with varied applications so that recall becomes fluent and is more likely to occur across different contexts and content domains. Simply stated, information that is frequently retrieved becomes more retrievable." [4]. However, once again, the pushback is generally related to the amount of content to cover in the limited amount of time provided. Nevertheless, if feedback continues to have such a positive impact on achievement, then educators must build in time to provide it. Once again, if teachers experience themselves what feedback does to improve their own learning, they will begin to accept and ultimately to pursue how to provide much needed feedback into their pedagogical practice.

Another practice that educators recognize is critical if learners are to become self-directed and pursue inquiry on their own is self-evaluation. In 2015, John Hattie's work on Visible Learning concluded that self-reported grades or self-evaluation had a 1.33 impact on student achievement [5].

This level of impact is not only substantial; but significant as well. So how does an educator, programmed to believe that only the teacher can determine the predicted level of success for the learner begin to turn the student into being the primary evaluator of his or her own learning in a productive manner for the student? Teachers struggle with the idea of releasing that responsibility completely to the students. Besides the fact that school authorities and parents expect teachers to be the primary evaluator, in many cases the teacher assigning grades is the only approved and legitimate process for evaluating student performance. However, once the realities are confronted, the struggle can be minimized if student self-evaluation is openly discussed in a group setting where teachers share what would help them as learners. Once again, hearing from peers what they value and what they consider important becomes an illuminative process that can ultimately yield the results needed. In many cases teachers feel they need "permission" to offer students opportunities to self-assess in a manner that can be counted that does not forgo accountability for the learner. As Halpern and Hakel state, "The underlying rationale for any kind of formal instruction is the assumption that knowledge, skills and attitudes learned in this setting (university) will be recalled accurately, and will be used in some other context at some time in the future. We only care about student performance in school because we believe that it predicts what students will remember and do when they are somewhere else and some other time. Yet we often teach and test as though the underlying rationale for education were to improve student performance in school. As a consequence, we rarely assess student learning in the context or at the time for which we are teaching." [4]. As powerful as the research says self-assessment is, ideas for implementation that have been tried and tested are not readily available. Therefore, a conversation of peers concerning this matter is the only way to provide teachers the courage and the practical ideas drawn from personal experience that will help teachers to take the leap and make the necessary changes in student evaluation. Just as students need exemplars to uncover their own strengths, to inform their work, teachers need ideas from their trusted peers as well. Students need to be able to answer, 
"What am I supposed to learn and how will I know when I have learned it?"

The fourth item on the list of innovations is authentic/real world learning. If a student asks, "Why am I learning this?" all teachers want to be able to tell them why without saying because it's on the high stakes test. When anyone is asked what makes a particular strategy meaning making leading to transfer, the temptation is to say, "When it's relevant." The challenge then becomes what makes learning relevant. At the risk of offering circular thinking, learning is relevant when it is connected to the real world, when it has meaning to the student. When teachers pose as learners and attempt to answer that question, they will observe that anything that is project-based is more likely to approximate real world learning than studying from a textbook. So how does a teacher create this relevancy and authenticity in a project so that the learning has depth and rigor and isn't just a waste of time? One question teachers need to ask themselves is, "How and where is what I teach used in the world outside of school? How can I approximate that experience?" The closer the connection to real world projects that draw the outside world into the academic setting, the more authentic the learning becomes. For example, if the teaching of math is just about problems disconnected from life, the processes used to solve the problem are promptly forgotten. Basically, the teacher seeks to design learning that throws the learner into ambiguity because no thinking is activated without ambiguity. Nevertheless, as teachers create challenges that connect students with real world experiences directly connected to the content, they must first identify high impact material that encourages creativity and exploration as noted by Cooper and Murphy. When the authentic learning episode is based on content that has high impact, the resulting experience will be solid and further promote a culture of inquiry [1].

The fifth hack possibility, assessing what matters most is directly related to the outcomes expected for the learner. Typically, educators assess what is easy to score. Assessing what matters is probably not going to be easy to score and will require exemplars, rubrics, and a clear set of expectations for students. When asked what were the characteristics of an outstanding assessment in their learning experience, educators typically cannot think of anything and must go outside the school setting to offer ideas on what made the assessment work. Actually, instructors creating valid assessments need to ask two questions. First, could the student actually fare well on the assessment and not understand the concept at all? Second, could the student fare poorly on the assessment and understand the concept thoroughly? If the answer is yes in either case, the instructor needs to go back and redesign. What does the assessment actually assess? Memorable assessments can take on multiple formats and designs and need to maintain student interest alive. One way to assure that the learning will be meaningful is to make sure the learner knows the goal, the audience, the performance, and the scoring criteria such as is the case in the performance task of Understanding by Design of Wiggins and McTighe [15]e.

Finally, one way to signal inquiry to the student and to stimulate engagement is the use of thoughtprovoking questions that allow the student to engage, explore, explain, elaborate, and evaluate. If teachers were asked how they as learners would respond to questions in meaning making, leading to transfer, they would immediately agree that the power of an open-ended question is an obvious motivational tool. The open-ended questions invite the learner into the discussion. The danger happens when questions posed can be answered after a brief Google search. McTighe and Wiggins have written a book on essential questions, a main component of Understanding by Design [8].

\section{Conclusion}

This study acknowledges that following professional development sessions, teachers, with good intention, generally revert back to their comfort zone and engage in their own tried and tested processes without a clear understanding of their rationale. Given that possibility, the research tool used in this study puts teachers back in the learner/empathy mode and makes the learning a community experience. In so doing, teachers see how their peers think, what they need to engage in lasting learning and begin to plan how they can incorporate their findings in their own instructional design. Beyond the tried and tested processes, teachers are often asked to transition into the newest research finding but fall short of their goal. By using this same tool, teachers can engage in the process as a group and begin to see how the idea can actually take shape in their own instructional design and delivery. Therefore, they are able to arrive at transfer in their own learning. The flexibility of the tool is its value for educators at any grade level.

\section{References}

[1] Cooper, R. and Murphy, E. (2016). Hacking Project Based Learning. Cleveland: Ohio:Times 10 Publications.

[2] eCampus News (2017). Re-Inventing Higher Ed.

[3] Guilott, M. and Parker, G. (2012). A value added decision. Denver, Colorado: Outskirts Press.

[4] Halpern, D. and Hakel, M. (2015). "Applying the Science of Learning to the University and Beyond." Change. Retrieved from http://www.baylor.edu/atl/ doc. 
php/250293.pdf (Access date: February $2^{\text {nd }}$ 2016).

[5] Hattie, J. (2009). What Doesn't Work in Education: The Politics of Distraction, London: Pearson, p. 49. Retrieved from http://visible-learning.org/2009/02/visiblelearning-meta-study./ (Access date: February $2^{\text {nd }} 2016$ )

[6] Hattie, J. (2015) What Works Best in Education: The Politics of Collaborative Expertise, London: Pearson, p. 1.

[7] Irvine, G. (2017). 4 Reasons why a generational skills gap exists today-and isn't closing. Retrieved from http://www.ecampusnews.com/curriculum/generationskills-gap-exists/. (Access date: February $2^{\text {nd }} 2016$ ).

[8] McTighe, J. and Wiggins, G.(2013). Essential Questions. Alexandria, VA: Association for Supervision and Curriculum Development.

[9] Pahomov, L. (2014). Authentic Learning in the Digital Age. Alexandria, VA: Association for Supervision and Curriculum Development.

[10] Pink, D. (2009). Drive: The Truth About What Motivates Us. New York: Riverhead Books.

[11] Sage on the Stage retrieved from:. (http://educationnext.org/sage-on-the-stage/) Summer

2011 Volume 11, Number 3. (Access date: February $2^{\text {nd }}$ 2016).

[12] Schlechty, P. (2014). Hidden curriculum. In S. Abbott (Ed.), The glossary of education reform. Retrieved from http://edglossary.org/hidden-curriculum. (Access date: February $2^{\text {nd }} 2016$ ).

[13] Urban, T. (2015) The AL Revolution: Road to Superintelligence. Retrieved from http://waitbutwhy.com/ 2015/01/artificial-intelligence-revolution-1.html (Access date: February $2^{\text {nd }} 2016$ )

[14] Web Forum: The future of jobs (2017)... Retrieved from http://reports.weforum.org/future-of-jobs-2016/share able-infographics/ (Access date: February $2^{\text {nd }}$ 2016).

[15] Wiggins, G. and McTighe J. (2005). Understanding by Design. Alexandria, VA: Association or Supervision and Curriculum Development.

[16] Wiggins, G. and McTighe, J. (2007). Schooling by Design. Alexandria, VA: Association for Supervision and Curriculum Development.

[17] Wiggins, G. and McTighe, J. (2007). The Understanding by Design Guide to Creating High-Quality Units. Alexandria. VA: Association for Supervision and Curriculum Development.

[18] Zañartu Correa. LM. "Aprendizaje colaborativo: una nueva forma de Diálogo Interpersonal y en Red." Revista Digital de Educación y nuevas tecnologías. número 28 año 5retrieved:http://contexto-educativo.com.ar/2003/4/nota02.htm (Access date: February $2^{\text {nd }} 2016$ ). 